\title{
PENELAAHAN FAKTOR YANG DAPAT MEMPENGARUHI PENETAPAN UKURAN SASARAN VENIR KAYU LAPIS
}

\section{(Assessing Factors That Affects the Determination of Targeted Veneer Size for Plywood)}

\author{
Oleh/By :
}

\author{
Eka Novriyanti $^{1)}$
}

\begin{abstract}
In order to acquire panel construction (i.e. plywood) with the desired thickness, it is essential to determine the targeted size of veneerpeeled from its logs. Particularfactors such as veneer shrinkage, panel-pressing magnitude, sanding, panel shrinkage, and variation in the overall log peeling can affect the determination of the targeted size of the peeled veneer. The experiment was conducted by collecting the related data that entailed veneer thickness afterpeeling $(1,76 \mathrm{~mm})$, veneer shrinkage (6,34\%), implemented pressing magnitude (11,94\%), the sanding effect $(0,44 \%)$, veneer thickness in panel $(1,22 \mathrm{~mm})$, final panel thickness $(28,02 \mathrm{~mm})$, and panel shrinkage $(1,42 \%)$. Those collected data were processed, analyzed, descriptively presented, and further simulated into particular quantitative formula. The resulting formula was then employed to determine the appropriate targeted size of peeled veneer for plywood with 19-ply assembly, i.e. 1,870 \pm $0,013 \mathrm{~mm}$.
\end{abstract}

Keywords: Plywood, veneer, targeted size, peeled veneer

\begin{abstract}
ABSTRAK
Untuk mendapatkan konstruksi panel yang memiliki ukuran tebal yang diinginkan, maka diperlukan penetapan ukuran sasaran pada saat pengupasan venir. Faktor-faktor penyusutan venir, pengempaan panel, pengampelasan, dan penyusutan panel serta keragaman pengupasan total dapat mempengaruhi penetapan ukuran sasaran. Data yang dikumpulkan dalam percobaan ini adalah adalah tebal venir sesudah kupas $1,76 \mathrm{~mm}$, penyusutan venir $6,34 \%$, pengaruh pengempaan $11,94 \%$, pengaruh pengampelasan $0,44 \%$, tebal venir dalam panel $1,22 \mathrm{~mm}$, rata-rata tebal panel akhir $28,02 \mathrm{~mm}$, dan penyusutan panel 1,42\%. Data-data tersebut selanjutnya diolah dengan formula yang diturunkan dari perubahan yang dialami venir sampai menjadi panel oleh proses produksi, untuk mendapatkan ukuran sasaran pengupasan venir kayu lapis konstruksi 19-lapis. Hasil perhitungan menunjukkan bahwa ukuran sasaran pengupasan venir adalah 1,870 $\pm 0,013 \mathrm{~mm}$.
\end{abstract}

Kata kunci: Kayu lapis, venir, ukuran sasaran pengupasan venir

${ }^{1}$ Peneliti pada Loka Litbang Hasil Hutan Bukan Kayu, Kuok-Riau 


\section{PENDAHULUAN}

Dalam industri kayu lapis (plywood), efisiensi bahan baku merupakan hal yang sangat diperhatikan agar dapat kompetitif dalam pasar dan menghemat kayu yang menjadi bahan baku industri ini. Merencanakan ukuran sasaran pengupasan venir (veneer) untuk kayu lapis merupakan salah satu alternatif untuk efisiensi bahan baku, karena pembentukan kayu lapis dimulai dengan pembuatan venir. Dengan perencanaan yang tepat, proses pengupasan log dengan mesin pengupas akan menghasilkan tebal venir yang diinginkan, tidak memboroskan bahan baku dan efisien dalam waktu proses produksi karena kayu lapis yang dihasilkan, tidak menjalani proses repair karena ukurannya yang tidak standar.

Venir yang dihasilkan dari pengupasan kayu bulat $(\log )$ menggunakan mesin kupas (peeling machine), dapat disetel untuk menghasilkan ketebalan venir sesuai tebal panel yang akan diproduksi. Lembaran-lembaran venir hasil kupasan akan membentuk kayu lapis yang disatukan dengan perekat dan menjalani proses pengempaan.

Tebal venir, penyusutan venir, tebal panel, penyusutan panel, pengempaan dan pengampelasan adalah faktor penentu dalam perhitungan ukuran sasaran. Dalam proses produksi, sejak venir dikupas hingga dihasilkannya panel yang diinginkan, secara sendirian maupun secara kesatuan dalam wujud panel, terjadi serangkaian proses produksi maupun proses alami yang akan menambah maupun mengurangi tebal venir dan panel. Penyusutan, merupakan proses alam yang dialami venir maupun panel. Pengempaan dan pengampelasan, merupakan proses produksi yang akan mereduksi tebal sekelompok venir dan garis rekat yang telah dirakit sebelumnya.

Kayu lapis merupakan produk industri perkayuan Indonesia yang sempat beberapa lama menjadi primadona, karena memasok sebagian besar dari kebutuhan dunia. Dewasa ini, perkembangan industri kayu lapis mengalami penurunan karena berkurangnya investasi dan kurangnya pasokan bahan baku dolog, terutama pasokan dari hutan alam yang telah semakin rusak.

Pasokan bahan baku yang semakin berkurang, dapat disiasati dengan efisiensi bahan baku dolog yang salah satunya dapat dilakukan dengan penetapan ukuran sasaran Tujuan penelitian ini adalah untuk menelaah dan memformulasikan suatu perhitungan untuk penetapan ukuran sasaran bagi pengupasan vinir kayu lapis dengan memperhatikan rangkaian proses produksi venir maupun panel yang berpengaruh pada tebal akhir panel yang diinginkan.

\section{BAHAN DAN METODE}

\section{A. Bahan dan Alat}

Penelitian dilakukan di industri kayu lapis komersial di Banjarmasin, Kalimantan Selatan. Bahan yang digunakan adalah kayu lapis container floor (CF) konstruksi 19 lapis dengan tebal $28 \mathrm{~mm}$, dan venir muka/bawah/inti pembentuknya dengan tebal hasil pengukuran rata-rata $1,76 \mathrm{~mm}$. Peralatan yang digunakan dalam penelitian ini berupa kaliper, micrometer, meteran, penggaris, moisture meter tester, oven, desikator, loupe scale, dan peralatan tulis. 


\section{B. Metode Penelitian}

Penelitian dilakukan dalam dua garis besar metode kegiatan, yaitu :

1. Pengamatan proses produksi kayu lapis CF konstruksi 19 lapis

Metode yang dilakukan adalah mengikuti dan mengamati alur produksi kayu lapis, penarikan contoh dan pengukuran variabel mulai dari pengupasan sampai ke divisi checking.

2. Penetapan model ukuran sasaran pengupasan venir

a. Pengukuran tebal venir dilakukan setelah pengupasan atau baru keluar dari mesin kupas dan setelah melewati mesin pengering (dryer), yang dilakukan pada masingmasing 30 sampel untuk masing-masing venir dengan arah serat sejajar arah panjang dan venir dengan arah serat tegak lurus arah panjangnya. Tebal venir merupakan ratarata dari pengukuran di 6 (enam) titik yang diukur menggunakan kaliper.

b. Pengukuran tebal panel dilakukan setelah melewati kempa dingin dan kempa panas serta setelah melewati mesin sander dan bagian pengawasan mutu (quality control) sebelum pengepakan dilakukan. Tebal panel merupakan rata-rata dari pengukuran menggunakan kaliper di 6 (enam) titik .

c. Untuk pengukuran penyusutan venir dan kayu lapis dilakukan dengan memasukkan bahan sampel (venir dengan tebal rata-rata $1,76 \mathrm{~mm}$ dan CF dengan tebal $28 \mathrm{~mm}$, masing-masing berukuran $(10 \times 10) \mathrm{mm}^{2}$ ke oven dengan suhu $103 \pm 2^{\circ} \mathrm{C}$ selama 3 jam dan didiamkan dalam desikator selama 1 jam. Pengovenan dilakukan selama 3 x 3 jam sampai dimensi bahan menjadi stabil (tidak berubah-ubah lagi).

d. Untuk mendapatkan tebal venir pada produk akhir (CF) dilakukan dengan mengukur tebal venir pada panel di tiga titik menggunakan loupe scale, dan nilai tebal venir adalah rata-rata dari ketiga pengukuran tersebut.

3. Penurunan formulasi perhitungan penetapan ukuran sasaran pengupasan venir:

a. Dasar-dasar penurunan rumus

Tebal akhir kayu lapis dipengaruhi oleh penyusutan venir dan panel, pengampelasan serta pengempaan panel. Faktor-faktor tersebut diasumsikan mempengaruhi panel sebagai satu kesatuan (merata pada seluruh bagian), kecuali pengampelasan yang berpengaruh pada permukaan panel. Dengan dasar-dasar asumsi dari proses-proses yang terjadi pada venir maupun panel, maka dapat diturunkan rumus untuk model perhitungan ukuran sasaran pengupasan vinir.

b. Model perhitungan ukuran sasaran pengupasan venir

- Tebal panel yang diinginkan

$\mathrm{TP}=$ Tst $-\Delta$ susut panel

$\mathrm{TP}=\mathrm{Tst}-(\Delta S h p / 100) T s t$

$\mathrm{TP}=(1-\Delta S h p / 100) T s t$

$T P$

$$
\text { Tst }=\frac{}{\underline{(1-\Delta \operatorname{Shp} / 100)}}
$$

Keterangan (Remark) : TP = tebal panel yang diinginkan (appropriate panel thickness) $(\mathrm{mm}) ;$ 'Tst = tebal panel setelah sander (panel thickness after sanding) $(\mathrm{mm})$; $\Delta \mathrm{Shp}=$ penyusutan panel (panel shrinkage $)(\%)$ 


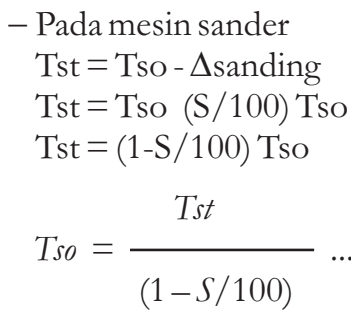

Keterangan (Remark): Tso = tebal panel sebelum sander (panel thickness before sanding) $(\mathrm{mm}) ; \mathrm{S}=$ pengurangan tebal karena ampelas (thick reduction because of sanding) $(\%)$.

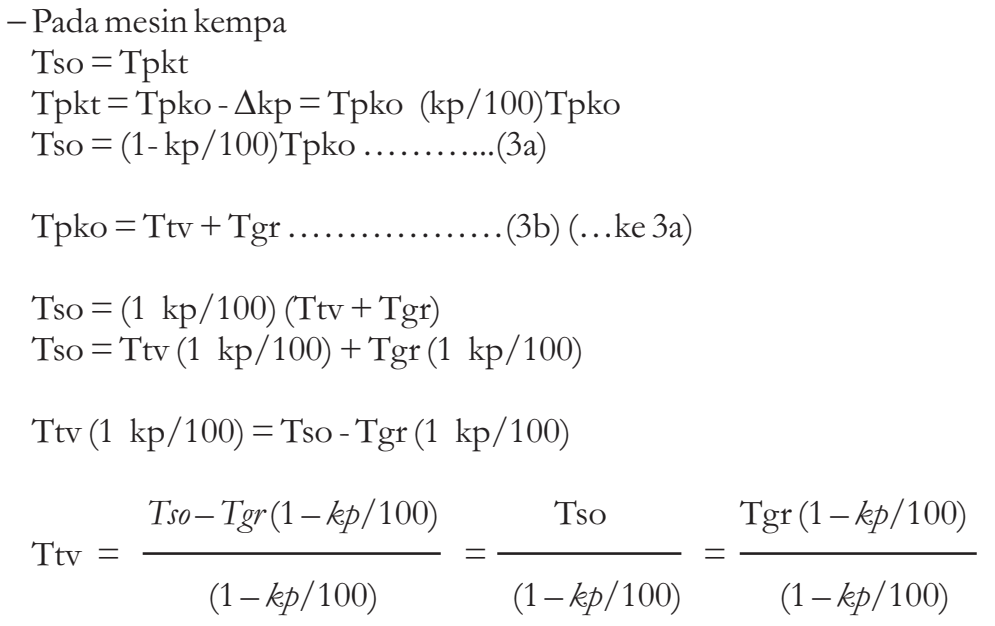

Keterangan $($ Remark $):$ Tpkt $=$ Tso $=$ tebal panel setelah kempa atau sebelum sander (panel thickness after pressing or before sanding) $(\mathrm{mm})$; Tpko = tebal panel sebelum kempa (panel thickness before pressing) $(\mathrm{mm}) ; \mathrm{Ttv}=$ total tebal vinir dalam panel sebelum kempa (total veneer thickness in panel before pressing) $(\mathrm{mm}) ; \operatorname{Tgr}=$ tebal garis rekat (thickness glue line in pane) $(\mathrm{mm}) ; \mathrm{kp}=$ pengurangan tebal karena pengaruh kempa (panel thickness reduction because of pressing) (\%).

- Perakitan pada glue spreader yang menghasilkan tebal sasaran venir pada panel ( $\mathrm{Tv}$ )

$$
\mathrm{Tv}=\mathrm{Ttv} / 19
$$

- Sebelum perakitan atau sesudah pengupasan dan pengeringan

Venir mengalami penyusutan sebelum dirakit, sehingga: 


$$
\begin{aligned}
& \operatorname{Tv}=\operatorname{Tvo}-\Delta s v \\
& \operatorname{Tv}=\operatorname{Tvo}(s v / 100) T_{v o}=(1-s v / 100) \operatorname{Tvo} \\
& T v o=\frac{T v}{(1-s v / 100)}
\end{aligned}
$$

Keterangan (Remark) : Tv = tebal venir rataan pada panel (mean of veneer thickness in panel) (mm); Tvo = tebal venir sebelum penyusutan atau tebal venir setelah pengupasan (veneer thickness after peeling) ( $\mathrm{mm}) ; \mathrm{sv}=$ penyusutan vinir (veneer shrinkage) (\%).

$$
\begin{aligned}
& \mathrm{T}=\mathrm{Tvo}+(\mathrm{zxst}) \\
& \text { Tv } \\
& =\longrightarrow+(\mathrm{zxst}) \\
& (1-s v / 100) \\
& =\frac{T t v / 19}{(1-s v / 100)}+(\mathrm{zxst}) \\
& \frac{T t v}{19(1-s v / 100)}+(\mathrm{zxst}) \\
& =\frac{(T s o / 1-k p / 100))-T g r}{10(1-s \nu / 100))}+(\mathrm{zxst}) \\
& 19(1-s v / 100) \\
& \begin{array}{l}
=\frac{((T s t / 1-S / 100)) /(1-k p / 100))-T g r}{19(1-s v / 100)}+ \\
=\frac{T s t}{\frac{(1-S / 100)(1-k p / 100)}{19(1-s v / 100)}-T g r}+(\mathrm{zx} \mathrm{st})
\end{array} \\
& =\frac{\frac{T P /(1-\Delta S h p / 100)}{(1-S / 100)(1-k p / 100)}-T g r}{19(1-s v / 100)}+(\mathrm{z} \times \mathrm{st}) \\
& \mathrm{T}=\frac{\frac{T P}{(1-\Delta S h p / 100)(1-S / 100)(1-k p / 100)}-\operatorname{Tg} r}{19(1-s v / 100)}+(\mathrm{z} \times \mathrm{st})
\end{aligned}
$$

Keterangan (Remark) : $\mathrm{T}=$ Ukuran sasaran pengupasan venir (Target size of veneer peeling) $(\mathrm{mm})$; TP = Tebal panel yang diinginkan (Appropriate panel thickness) $(\mathrm{mm}) ; \Delta \mathrm{Shp}=$ Penyusutan panel (Panel shrinkage) $(\%) ; \mathrm{S}=$ Pengurangan tebal karena ampelas (Thick reduction because of sanding) (\%); $\mathrm{Kp}=$ Pengurangan tebal panel karena pengaruh kempa (Panel thickness 
reduction because of pressing) (\%); $\mathrm{Tgr}=$ Total garis rekat (Thickness glue line in panel) $(\mathrm{mm}) ; \mathrm{Sv}_{\mathrm{v}}=$ Penyusutan venir (Veneer shrinkage) $(\%) ; \mathrm{st}=$ Keragaman total pengupasan (Total variance of peeling); $\mathrm{Z}=$ Nilai tabel Z pada taraf nyata 0,05 (Value in table $Z$ at level 0,05 ).

\section{Analisis Data}

Data yang dikumpulkan dianalisis secara deskriptif dan disimulasikan pada model formula (yang diturunkan dari perhitungan berdasarkan proses produksi yang terjadi pada venir/panel sampai dihasilkannya produk jadi) guna mendapatkan ukuran sasaran pengupasan vinir yang dibutuhkan untuk konstruksi panel yang diteliti.

\section{HASIL DAN PEMBAHASAN}

\section{A. Proses Pembentukan Kayu Lapis}

Secara garis besar proses produksi kayu lapis dapat dikelompokkan menjadi dua seksi proses, yaitu seksi proses I yang meliputi persiapan log dan pembuatan venir; serta seksi proses II yang meliputi perakitan bahan menjadi kayu lapis, pengerjaan akhir, dan inspeksi.

Dalam seksi proses I, terdapat tahap-tahap sebagai berikut: pengupasan log (peeling); penggulungan pemotongan/penyusunan dan venir; pengeringan venir; dan persiapan venir (Gambar 1). Dalam seksi proses I, terdapat istilah produksi rendum yang berarti venir hasil kupasan yang kurang bagus, terputus-putus, sehingga tidak bisa digulung tapi langsung disesuaikan ukurannya dan disusun. Sedangkan dalam proses II, terdapat tahapan-tahapan pencampuran perekat; perakitan; dan tahap akhir. Proses pendempulan, pemotongan, pengampelasan panel adalah serangkaian kegiatan yang termasuk dalam tahap akhir pengerjaan panel.

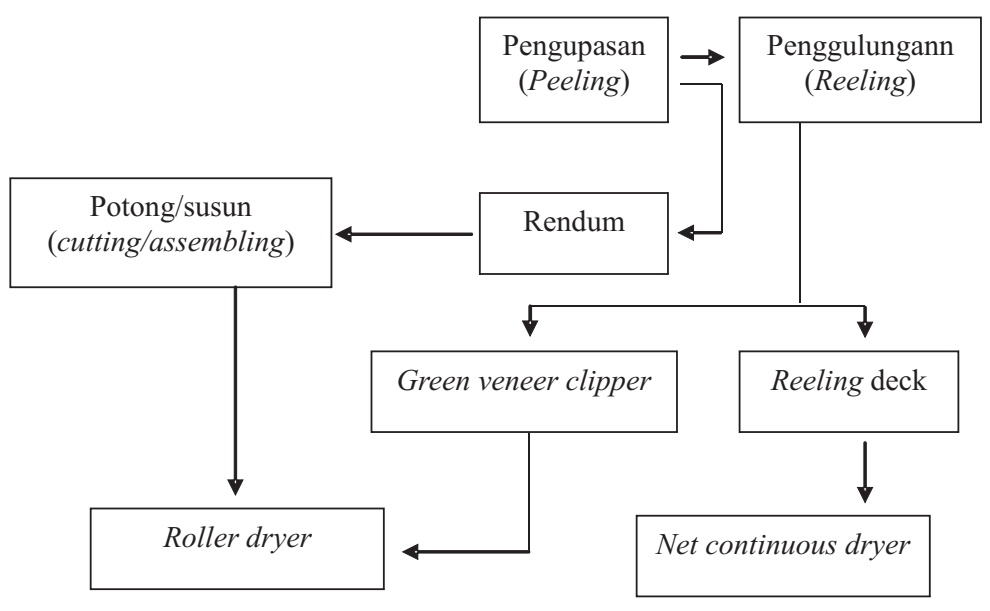

Gambar 1. Alur proses pengupasan venir Figure 1. Flow chart of veneer peeling 
Dalam setiap proses pembentukan venir sampai venir tersebut akhirnya menjadi panel yang diinginkan, venir menjalani serangkaian perlakuan yang menyebabkan penyusutan dan mempengaruhi ukuran dimensinya. Pengeringan, penyusunan venir dan perekatan, pengempaan, serta pengampelasan adalah diantara proses yang mempengaruhi dimensi venir.

\section{B. Model Penetapan Ukuran Sasaran Pengupasan Venir}

1. Perhitungan menggunakan data pengamatan

Data pengamatan terdapat pada lampiran dan berikut disampaikan hasil perhitungan menggunakan model yang telah dirumuskan pada metode penelitian:

a. Perhitungan untuk keragaman total

Perhitungan ini dilakukan berdasarkan hasil pengamatan pada Lampiran 1, sebagai berikut:

$\mathrm{Rw} \operatorname{rataan}($ Average $)=0,12$

$\mathrm{Rb}$ rataan $($ Average $)=0,33$

$\mathrm{Sw}=\mathrm{Rw}$ rataan $($ average $) / \mathrm{d} 2$, dimana (where) $\mathrm{d} 2=2,534$ untuk (for $) \mathrm{n}=6$

$=0,12 / 2,534$

$=0,052$

$\mathrm{Sb}=\sqrt{\left((\text { Rbrataan } / d 2)^{2}-S w^{2} / n\right)}$ dimana (where) $\mathrm{d} 2=4,639$ untuk (for) $\mathrm{n}=60$

$=\sqrt{\left((0,33 / 4,639)^{2}-0,052^{2} / 6\right)}$

$=0,067$

St $=\sqrt{S b^{2}+S w^{2}}$

$=0,085$

b. Perhitungan untuk ukuran sasaran pengupasan venir

Kadar air CF menurut standar adalah 10\%, jadi dengan hasil dari Tabel 1, penyusutan vinir dari mesin dryer adalah :

Penyusutan vinir (veneer shrinkage) $(\mathrm{Sv})=(30 \% 10 \%) / 30 \% \times 6,34 \%=4,23 \%$

KA panel menurut standar BS-6656 (1985) dalam Anonim (1999) adalah maksimum 14\%, sehingga dengan hasil dari Tabel 2 , penyusutan panel dapat dihitung sebagai berikut: Penyusutan panel $(\Delta \mathrm{Shp})=(30 \%-14 \%) / 30 \% \times 1,42 \%=0,76 \%$

Dari hasil pengamatan pada Tabel 3 dan perhitungan yang telah dilakukan di atas, maka diketahui : $\mathrm{TP}=28,00 \mathrm{~mm} ; \Delta \mathrm{Shp}=0,76 \% ; \mathrm{Sv}=4,23 \% ; \mathrm{S}=0,44 \% ; \mathrm{Tgr}=0,605 ; \mathrm{Kp}=$ $11,94 \% ;$ St $=0,085 ; Z=1,65$ pada taraf nyata 0,05 . 
Tabel1. Hasil pengukuran penyusutan venir karena proses pengeringan mesin dryer Table 1. Result of measurement on veneer shrinkage because of drying process

\begin{tabular}{|c|c|c|c|c|}
\hline $\begin{array}{l}\text { Contoh ke- } \\
\text { (Sample } \\
\text { number) }\end{array}$ & $\begin{array}{c}\text { Tebal awal } \\
\text { (Initial thickness) } \\
(\mathrm{mm})\end{array}$ & $\begin{array}{c}\text { Tebal akhir } \\
\text { (Final thickness) } \\
(\mathrm{mm})\end{array}$ & $\begin{array}{c}\text { Selisih tebal } \\
\text { (Thickness reduction) } \\
(\mathrm{mm})\end{array}$ & $\begin{array}{c}\text { Penyusutan } \\
\text { (Shrinkage) } \\
(\%) \\
\end{array}$ \\
\hline 1 & 1,76 & 1,64 & 0,12 & 6,82 \\
\hline 2 & 1,76 & 1,62 & 0,14 & 7,95 \\
\hline 3 & 1,78 & 1,66 & 0,12 & 6,74 \\
\hline 4 & 1,76 & 1,58 & 0,18 & 10,23 \\
\hline 5 & 1,74 & 1,63 & 0,11 & 6,32 \\
\hline 6 & 1,72 & 1,60 & 0,12 & 6,98 \\
\hline 7 & 1,75 & 1,60 & 0,15 & 8,57 \\
\hline 8 & 1,73 & 1,63 & 0,10 & 5,78 \\
\hline 9 & 1,67 & 1,59 & 0,08 & 4,79 \\
\hline 10 & 1,78 & 1,62 & 0,16 & 8,99 \\
\hline 11 & 1,75 & 1,59 & 0,16 & 9,14 \\
\hline 12 & 1,82 & 1,69 & 0,13 & 7,14 \\
\hline 13 & 1,75 & 1,65 & 0,10 & 5,71 \\
\hline 14 & 1,73 & 1,63 & 0,10 & 5,78 \\
\hline 15 & 1,71 & 1,63 & 0,08 & 4,68 \\
\hline 16 & 1,71 & 1,62 & 0,09 & 5,26 \\
\hline 17 & 1,68 & 1,61 & 0,07 & 4,17 \\
\hline 18 & 1,73 & 1,61 & 0,12 & 6,94 \\
\hline 19 & 1,71 & 1,63 & 0,08 & 4,68 \\
\hline 20 & 1,68 & 1,60 & 0,08 & 4,76 \\
\hline 21 & 1,73 & 1,59 & 0,14 & 8,09 \\
\hline 22 & 1,73 & 1,64 & 0,09 & 5,20 \\
\hline 23 & 1,75 & 1,65 & 0,10 & 5,71 \\
\hline 24 & 1,75 & 1,65 & 0,10 & 5,71 \\
\hline 25 & 1,72 & 1,62 & 0,10 & 5,81 \\
\hline 26 & 1,67 & 1,60 & 0,07 & 4,19 \\
\hline 27 & 1,75 & 1,64 & 0,11 & 6,29 \\
\hline 28 & 1,71 & 1,61 & 0,10 & 5,85 \\
\hline 29 & 1,71 & 1,62 & 0,09 & 5,26 \\
\hline \multirow[t]{2}{*}{30} & 1,77 & 1,65 & 0,12 & 6,78 \\
\hline & & & Rataan (Mean) & 6,34 \\
\hline
\end{tabular}


Tabel 2. Pengukuran penyusutan panel (CF) dengan metode oven Table 2. Shrinkage measurement of panel (CF) with oven method

\begin{tabular}{c|c|c|c|c}
\hline $\begin{array}{c}\text { No } \\
\text { sample }\end{array}$ & $\begin{array}{c}\text { T Ra } \\
(\mathrm{mm})\end{array}$ & $\begin{array}{c}\text { TRt } \\
(\mathrm{mm})\end{array}$ & $\begin{array}{c}\text { TRa-TRt } \\
(\mathrm{mm})\end{array}$ & $\begin{array}{c}\mathrm{KA}=(\mathrm{TRa}-\mathrm{TRt}) / \text { Tra } \mathrm{x} \\
100 \% \\
(\%)\end{array}$ \\
\hline 1 & 28,04 & 27,70 & 0,34 & 1,21 \\
2 & 28,19 & 27,63 & 0,56 & 1,99 \\
3 & 28,17 & 27,69 & 0,48 & 1,70 \\
4 & 28,15 & 27,74 & 0,41 & 1,46 \\
5 & 28,10 & 27,58 & 0,52 & 1,85 \\
6 & 28,01 & 27,64 & 0,37 & 1,32 \\
7 & 28,05 & 27,76 & 0,29 & 1,03 \\
8 & 28,06 & 27,70 & 0,36 & 1,28 \\
9 & 28,03 & 27,70 & 0,33 & 1,18 \\
10 & 28,02 & 27,70 & 0,32 & 1,14 \\
\hline \multicolumn{2}{c}{ Rataan (Mean $)$} & & & 1,42 \\
\hline
\end{tabular}

Keterangan (Remarks): TRa = Tebal awal rataan panel sebelum dioven (Initial panel thickness); TRt $=$ Tebal akhir rataan panel setelah dioven (Overdue panel thickness after oven); KA = Kadar air panel (Moisture content)

Tabel3. Pengaruh proses produksi terhadap ketebalan panel

Table 3. Effect of production process on panel tbickness

\begin{tabular}{c|c|c|c|c|c|c}
\hline $\begin{array}{c}\text { Contoh ke- } \\
\text { (Sample number })\end{array}$ & $\begin{array}{c}\text { TPC } \\
(\mathrm{mm})\end{array}$ & $\begin{array}{c}\mathrm{TPH} \\
(\mathrm{mm})\end{array}$ & $\begin{array}{c}\mathrm{Kp} \\
(\%)\end{array}$ & $\begin{array}{c}\mathrm{Ts} \\
(\mathrm{mm})\end{array}$ & $\begin{array}{c}\text { ?s } \\
(\mathrm{mm})\end{array}$ & $\begin{array}{c}\mathrm{S} \\
(\%)\end{array}$ \\
\hline 1 & 32,07 & 28,39 & 11,47 & 28,29 & 0,10 & 0,35 \\
2 & 32,44 & 28,95 & 10,76 & 28,70 & 0,25 & 0,86 \\
3 & 32,72 & 28,29 & 13,54 & 28,16 & 0,13 & 0,46 \\
4 & 32,08 & 28,21 & 12,06 & 28,09 & 0,12 & 0,43 \\
5 & 32,73 & 28,61 & 12,59 & 28,51 & 0,10 & 0,35 \\
6 & 32,66 & 28,46 & 12,86 & 28,39 & 0,07 & 0,25 \\
7 & 31,01 & 28,49 & 8,13 & 28,35 & 0,14 & 0,49 \\
8 & 32,08 & 27,78 & 13,40 & 27,74 & 0,04 & 0,14 \\
9 & 31,98 & 27,86 & 12,88 & 27,64 & 0,22 & 0,79 \\
10 & 31,45 & 27,77 & 11,70 & 27,70 & 0,07 & 0,25 \\
\hline \multicolumn{2}{l|}{ Rataan } & 28,28 & 11,94 & 28,16 & 0,12 & 0,44 \\
\hline
\end{tabular}

Keterangan (Remarks): TPC = Tebal panel di kempa dingin (Panel thickness at cold press); TPH = Tebal panel di kempa panas (Panel thickness at hot press); Kp = Pengurangan tebal karena kempa (Thickness reduction because of pressing); $\mathrm{Ts}=$ Tebal panel di mesin ampelas (Panel thickness at sander); $\Delta \mathrm{s}=$ Tebal pengampelasan atau selisih tebal panel setelah kempa dan setelah ampelas (Sanding thickness or the thickness difference before and after sanding); $\mathrm{S}=$ Pengaruh pengampelasan (Sanding effect). 


$$
\begin{aligned}
\mathrm{T} & =\frac{\frac{T P}{(1-\Delta S h p / 100)(1-S / 100)(1-k p / 100)}-\operatorname{Tg} r}{19(1-s v / 100)}+(\mathrm{zx} \mathrm{st}) \\
& =\frac{\frac{28}{(1-0,76 / 100)(1-0,44 / 100)(1-11,94 / 100)}-0,605}{19(1-4,23 / 100)}+(1,65 \times 0,085) \\
& =1,73+0,14 \mathrm{~mm} \\
& =1,87 \mathrm{~mm}
\end{aligned}
$$

Hasil analisa data menggunakan model perhitungan yang telah dirumuskan menunjukkan bahwa untuk memperoleh kayu lapis konstruksi 19 lapis berukuran tebal $28 \mathrm{~mm}$, maka diperlukan ukuran sasaran pengupasan venir dengan nilai 1,87 $\mathrm{mm}$ dengan selang kepercayaan $(1,87 \pm 0,013) \mathrm{mm}$. Hal ini berarti mesin rotary memerlukan pengaturan (setting) untuk melakukan pengupasan log agar menghasilkan lembaran venir setebal 1,87 $\mathrm{mm}$. Dalam penelitian ini, hasil pengukuran pengupasan venir oleh mesin rotary adalah 1,76 $\mathrm{mm}$ (Tabel 1). Dengan tebal pengupasan 1,76 mm, maka dari model perhitungan akan dihasilkan tebal panel konstruksi 19 lapis sebesar 26,17 mm atau kurang 1,83 mm dari tebal panel yang ditargetkan yaitu 28,00 mm. Berdasarkan standar BS-6566 (1985) dalam Anonim (1999), batas atas dan bawah tebal panel adalah $-0,8 \mathrm{~mm}$ dan $+0,8 \mathrm{~mm}$, dan menurut standar JPIC (1997) dalam Anonim (1999) untuk ketebalan panel > 12,7 mm wilayah yang dibolehkan adalah $-0,8 \mathrm{~mm}$ dan $+0,8 \mathrm{~mm}$. Hal ini berarti panel yang dihasilkan dapat tergolong afkir karena mengalami under size sehingga harus mengalami pengerjaan ulang.

\section{KESIMPULAN}

1. Ukuran sasaran pengupasan venir dengan target panel setebal $28 \mathrm{~mm}$ konstruksi 19 lapis adalah 1,87 $\mathrm{mm}$ dengan selang kepercayaan $(1,87 \pm 0,013) \mathrm{mm}$. Hasil pengukuran aktual tebal venir adalah $1,76 \mathrm{~mm}$, sehingga terdapat kekurangan $0,11 \mathrm{~mm}$ dari tebal ukuran sasaran pengupasannya.

2. Faktor yang mempengaruhi penetapan ukuran sasaran pengupasan venir adalah penyusutan venir, pengempaan panel, pengampelasan, dan penyusutan panel serta keragaman pengupasan total.

3. Pada ukuran sasaran, tebal akhir dari panel tidak akan mengalami under size ataupun over size sehingga ditolak pembeli. Secara tidak langsung dengan adanya penetapan ukuran sasaran ini akan mengurangi ketidakefesienan penggunaan bahan baku dan juga mengurangi biaya yang muncul karena pengerjaan ulang. Hal tersebut dapat lebih menjamin mutu hasil venir dan menciptakan kepercayaan pengguna (konsumen). 


\section{DAFTAR PUSTAKA}

Anonim. 1983. Metode cara uji kayu lapis standar industri Indonesia (SII) 0404-80. Departemen Perindustrian. Jakarta.

1966. Plywood and Other Wood Based Panel. FAO, United Nation. Rome.

1998. Studi tentang industri dan pemasaran plywood di Indonesia. PT Capricorn Indonesia Co. Inc. Jakarta.

1999. TRP Standard. PT Tanjung Raya Plywood, dokumen perusahaan. Banjarmasin. (Tidak dipublikasikan).

Reksohadiprojo, S. dan I Gito Sudarmo. 1986. Manajemen Produksi. Balai Penerbit Fakultas Ekonomi Universitas Gadjah Mada. Yogyakarta.

Sutigno, P. 1985. Pengujian Kayu Lapis. Pusat Penelitian dan Pengembangan Kehutanan Departemen Kehutanan (Sirkulasi terbatas). Bogor. 
Lampiran 1. Hasil pengukuran tebal venir hasil pengupasan rotary Appendix 1. Result of measurement on veneer thickness from rotary peeling

\begin{tabular}{|c|c|c|c|c|c|c|c|c|}
\hline \multirow{2}{*}{$\begin{array}{c}\text { Contoh ke- } \\
\text { (Sample } \\
\text { number) }\end{array}$} & \multicolumn{6}{|c|}{ Ulangan pengukuran (Replication of measurement) } & \multirow{2}{*}{$\begin{array}{c}\mathrm{X} \\
(\mathrm{mm})\end{array}$} & \multirow{2}{*}{$\mathrm{Rw}$} \\
\hline & 1 & 2 & 3 & 4 & 5 & 6 & & \\
\hline 1 & 1,75 & 1,89 & 1,64 & 1,74 & 1,76 & 1,79 & 1,76 & 0,25 \\
\hline 2 & 1,74 & 1,69 & 1,73 & 1,76 & 1,85 & 1,80 & 1,76 & 0,16 \\
\hline 3 & 1,74 & 1,72 & 1,81 & 1,88 & 1,75 & 1,77 & 1,78 & 0,16 \\
\hline 4 & 1,77 & 1,72 & 1,78 & 1,71 & 1,79 & 1,70 & 1,75 & 0,11 \\
\hline 5 & 1,78 & 1,71 & 1,72 & 1,81 & 1,68 & 1,71 & 1,74 & 0,10 \\
\hline 6 & 1,73 & 1,69 & 1,67 & 1,74 & 1,73 & 1,78 & 1,72 & 0,11 \\
\hline 7 & 1,80 & 1,80 & 1,72 & 1,74 & 1,66 & 1,78 & 1,75 & 0,11 \\
\hline 8 & 1,72 & 1,81 & 1,72 & 1,69 & 1,71 & 1,73 & 1,73 & 0,11 \\
\hline 9 & 1,71 & 1,68 & 1,71 & 1,68 & 1,60 & 1,64 & 1,67 & 0,11 \\
\hline 10 & 1,81 & 1,77 & 1,70 & 1,79 & 1,85 & 1,75 & 1,78 & 0,15 \\
\hline 11 & 1,75 & 1,69 & 1,81 & 1,67 & 1,69 & 1,84 & 1,74 & 0,17 \\
\hline 12 & 1,82 & 1,93 & 1,82 & 1,79 & 1,77 & 1,79 & 1,82 & 0,16 \\
\hline 13 & 1,77 & 1,86 & 1,74 & 1,67 & 1,78 & 1,69 & 1,75 & 0,19 \\
\hline 14 & 1,73 & 1,71 & 1,74 & 1,75 & 1,77 & 1,70 & 1,73 & 0,07 \\
\hline 15 & 1,73 & 1,72 & 1,70 & 1,71 & 1,66 & 1,74 & 1,71 & 0,08 \\
\hline 16 & 1,73 & 1,70 & 1,62 & 1,79 & 1,73 & 1,70 & 1,71 & 0,17 \\
\hline 17 & 1,70 & 1,65 & 1,75 & 1,66 & 1,68 & 1,68 & 1,69 & 0,10 \\
\hline 18 & 1,66 & 1,72 & 1,67 & 1,78 & 1,83 & 1,73 & 1,73 & 0,17 \\
\hline 19 & 1,75 & 1,68 & 1,73 & 1,75 & 1,66 & 1,70 & 1,71 & 0,09 \\
\hline 20 & 1,71 & 1,69 & 1,67 & 1,68 & 1,63 & 1,69 & 1,68 & 0,08 \\
\hline 21 & 1,74 & 1,79 & 1,76 & 1,73 & 1,67 & 1,73 & 1,74 & 0,12 \\
\hline 22 & 1,74 & 1,75 & 1,70 & 1,77 & 1,69 & 1,70 & 1,73 & 0,08 \\
\hline 23 & 1,79 & 1,82 & 1,82 & 1,68 & 1,67 & 1,74 & 1,75 & 0,15 \\
\hline 24 & 1,74 & 1,72 & 1,74 & 1,75 & 1,78 & 1,75 & 1,75 & 0,06 \\
\hline 25 & 1,77 & 1,75 & 1,76 & 1,68 & 1,68 & 1,72 & 1,73 & 0,09 \\
\hline 26 & 1,70 & 1,61 & 1,64 & 1,69 & 1,71 & 1,71 & 1,68 & 0,10 \\
\hline 27 & 1,78 & 1,75 & 1,73 & 1,71 & 1,72 & 1,85 & 1,76 & 0,14 \\
\hline 28 & 1,68 & 1,66 & 1,67 & 1,75 & 1,80 & 1,71 & 1,71 & 0,14 \\
\hline 29 & 1,73 & 1,72 & 1,77 & 1,67 & 1,70 & 1,68 & 1,71 & 0,10 \\
\hline 30 & 1,76 & 1,78 & 1,76 & 1,71 & 1,85 & 1,73 & 1,77 & 0,14 \\
\hline 31 & 1,85 & 1,91 & 1,83 & 1,78 & 1,78 & 1,77 & 1,82 & 0,14 \\
\hline 32 & 1,96 & 1,75 & 1,76 & 1,95 & 1,97 & 1,99 & 1,90 & 0,24 \\
\hline 33 & 1,88 & 1,97 & 1,99 & 1,97 & 1,92 & 1,78 & 1,92 & 0,19 \\
\hline 34 & 1,95 & 1,81 & 1,77 & 1,98 & 1,96 & 1,87 & 1,89 & 0,21 \\
\hline 35 & 1,87 & 1,77 & 1,88 & 1,86 & 1,82 & 1,82 & 1,84 & 0,11 \\
\hline 36 & 1,82 & 1,84 & 1,87 & 1,79 & 1,85 & 1,78 & 1,83 & 0,09 \\
\hline 37 & 1,79 & 1,85 & 1,85 & 1,87 & 1,81 & 1,90 & 1,85 & 0,11 \\
\hline 38 & 1,87 & 1,78 & 1,85 & 1,71 & 1,77 & 1,80 & 1,80 & 0,16 \\
\hline 39 & 1,70 & 1,76 & 1,73 & 1,76 & 1,76 & 1,78 & 1,75 & 0,08 \\
\hline 40 & 1,87 & 1,77 & 1,83 & 1,76 & 1,74 & 1,80 & 1,80 & 0,13 \\
\hline 41 & 1,86 & 1,72 & 1,83 & 1,82 & 1,78 & 1,77 & 1,80 & 0,14 \\
\hline 42 & 1,80 & 1,79 & 1,82 & 1,79 & 1,82 & 1,79 & 1,80 & 0,03 \\
\hline 43 & 1,74 & 1,71 & 1,85 & 1,83 & 1,80 & 1,71 & 1,77 & 0,14 \\
\hline 44 & 1,86 & 1,90 & 1,86 & 1,75 & 1,77 & 1,72 & 1,81 & 0,18 \\
\hline 45 & 1,74 & 1,83 & 1,87 & 1,75 & 1,76 & 1,84 & 1,80 & 0,13 \\
\hline 46 & 1,74 & 1,70 & 1,70 & 1,74 & 1,72 & 1,78 & 1,73 & 0,08 \\
\hline
\end{tabular}




\section{Lampiran 1. Lanjutan}

\section{Appendix 1. Continued}

\begin{tabular}{|c|c|c|c|c|c|c|c|c|}
\hline \multirow{2}{*}{$\begin{array}{c}\text { Contoh ke- } \\
\text { (Sample } \\
\text { number) }\end{array}$} & \multicolumn{6}{|c|}{ Ulangan pengukuran (Replication of measurement) } & \multirow{2}{*}{$\underset{(\mathrm{mm})}{\mathrm{X}}$} & \multirow{2}{*}{ Rw } \\
\hline & 1 & 2 & 3 & 4 & 5 & 6 & & \\
\hline 47 & 1,74 & 1,72 & 1,70 & 1,77 & 1,71 & 1,70 & 1,72 & 0,07 \\
\hline 48 & 1,70 & 1,73 & 1,73 & 1,76 & 1,74 & 1,76 & 1,74 & 0,06 \\
\hline 49 & 1,72 & 1,73 & 1,75 & 1,71 & 1,77 & 1,78 & 1,74 & 0,07 \\
\hline 50 & 1,71 & 1,82 & 1,74 & 1,82 & 1,78 & 1,73 & 1,77 & 0,11 \\
\hline 51 & 1,70 & 1,81 & 1,76 & 1,70 & 1,79 & 1,81 & 1,76 & 0,11 \\
\hline 52 & 1,78 & 1,76 & 1,77 & 1,72 & 1,78 & 1,71 & 1,75 & 0,07 \\
\hline 53 & 1,68 & 1,67 & 1,71 & 1,72 & 1,74 & 1,74 & 1,71 & 0,07 \\
\hline 54 & 1,69 & 1,66 & 1,72 & 1,74 & 1,74 & 1,81 & 1,73 & 0,15 \\
\hline 55 & 1,72 & 1,75 & 1,76 & 1,76 & 1,84 & 1,79 & 1,77 & 0,12 \\
\hline 56 & 1,77 & 1,71 & 1,74 & 1,69 & 1,70 & 1,78 & 1,73 & 0,09 \\
\hline 57 & 1,70 & 1,71 & 1,73 & 1,75 & 1,68 & 1,71 & 1,71 & 0,07 \\
\hline 58 & 1,71 & 1,70 & 1,68 & 1,70 & 1,70 & 1,76 & 1,71 & 0,08 \\
\hline 59 & 1,74 & 1,64 & 1,79 & 1,79 & 1,72 & 1,72 & 1,73 & 0,15 \\
\hline 60 & 1,80 & 1,70 & 1,72 & 1,76 & 1,75 & 1,71 & 1,74 & 0,10 \\
\hline \multicolumn{2}{|c|}{ Rataan (Mean) } & & & & & & 1,76 & 0,12 \\
\hline $\mathrm{Rb}$ & 0,30 & 0,36 & 0,28 & 0,32 & 0,37 & 0,35 & 0,33 & \\
\hline
\end{tabular}

Keterangan (Remarks) : $\mathrm{R}=$ Wilayah $($ Range $)=$ Nilai data tertinggi (The highest data value $)$ - Nilai data terendah (The lowest data value); $\mathrm{Rw}=$ Wilayah ulangan dalam sample yang sama (Range of replication within the same sample); $\mathrm{Rb}=$ Wilayah antar sample untuk ulangan ke-i (Range between sample for replication- $\imath$ ) 
Lampiran 2. Data hasil pengukuran tebal plywood (CF) $28 \mathrm{~mm}$ Appendix 2. Result of measurement of $28,00 \mathrm{~mm}$ thick plywood (CF)

\begin{tabular}{c|c|c|c|c|c}
\hline \multirow{2}{*}{$\begin{array}{c}\text { Contoh ke- } \\
\text { (Sample number) }\end{array}$} & \multicolumn{3}{|c|}{ Ulangan pengukuran } & \multirow{2}{*}{$\begin{array}{c}\mathrm{X} \\
\text { (Repeated mesurement), mm }\end{array}$} & $\mathrm{Rw}$ \\
\cline { 2 - 4 } & 1 & 2 & 3 & & \\
\hline 1 & 27,98 & 27,89 & 28,08 & 27,98 & 0,19 \\
2 & 27,71 & 27,68 & 27,83 & 27,74 & 0,15 \\
3 & 27,98 & 27,76 & 27,67 & 27,80 & 0,31 \\
4 & 28,39 & 28,10 & 28,09 & 28,19 & 0,30 \\
5 & 27,87 & 27,82 & 27,87 & 27,85 & 0,05 \\
6 & 27,95 & 27,95 & 27,92 & 27,94 & 0,03 \\
7 & 27,84 & 27,79 & 27,85 & 27,83 & 0,06 \\
8 & 28,12 & 28,12 & 28,35 & 28,20 & 0,23 \\
9 & 27,81 & 27,76 & 27,82 & 27,80 & 0,06 \\
10 & 27,94 & 27,94 & 28,09 & 27,99 & 0,15 \\
11 & 27,81 & 27,79 & 27,76 & 27,79 & 0,05 \\
12 & 28,14 & 28,09 & 28,10 & 28,11 & 0,05 \\
13 & 28,16 & 28,13 & 28,17 & 28,15 & 0,04 \\
14 & 28,21 & 28,16 & 28,16 & 28,18 & 0,05 \\
15 & 28,08 & 28,08 & 28,13 & 28,10 & 0,05 \\
16 & 28,22 & 28,27 & 28,21 & 28,23 & 0,06 \\
17 & 28,14 & 28,14 & 28,10 & 28,13 & 0,06 \\
18 & 28,21 & 28,12 & 28,13 & 28,15 & 0,09 \\
19 & 28,08 & 28,06 & 28,13 & 28,09 & 0,07 \\
20 & 28,18 & 28,13 & 28,15 & 28,15 & 0,05 \\
\hline Sb & 28,04 & 27,99 & 28,03 & 28,02 & 0,11 \\
\hline Rataannnnnnn (Means) & 0,68 & 0,51 & 0,68 & 0,62 & \\
\hline
\end{tabular}

Keterangan (Remarks) : Rw = Wilayah ulangan dalam sample yang sama (Range of replication within the same sample $)=$ Nilai data tertinggi (The highest data value $)$ - Nilai data terendah (The lowest data value); $\mathrm{Sb}=$ Simpangan baku (Standar deviation) 